\title{
When Royalty Steps Forth. Role Drama as an Embodied Collective Learning System
}

\author{
LYNN FELS \\ Simon Fraser University (Canada)
}

\begin{abstract}
The article explores the interplay between complexity theory, performative inquiry and learning as the author shares her experience in role as a tinker in a role drama designed and facilitated by four pre-service teachers in her drama in education course. The reader is invited to consider role drama as an embodied learning system. Using the role drama as her example, the author identifies five conditions of a complex learning system as identified by complexity in education theorists Brent Davis, Dennis Sumara, and Elaine Simmt in their 2003 article, Complexity and Collectivity: On the Emergence of a Few Ideas. The author and her conspirators in role engaged in the overthrow of the monarchy are startled when the king suddenly announces his presence. What learning emerges when the king steps forth, and the tinker, alone, is faced with saving a fledging democratic movement?
\end{abstract}

I remember attending the first complexity science and educational research conference in Edmonton, Alberta in 2003 during which time a number of the presenters used a variety of complicated graphs and Venn diagrams in their attempts to language their understanding of complexity in education. A couple of us turned to drama and music to call attention to emergent possibilities through these mediums of engagement. But we were in the minority. Four years later, conference organizers invited contributors to view complexity in education through the lens of visual and performing arts, an invitation that many of us, arts educators and curriculum theorists, welcomed with delight.

Recognition of the possibilities of complexity as a theoretical underpinning for emergent learning through the arts continues to intrigue. Currently I teach courses on performative inquiry and drama education in a faculty of education, and am encouraged by the understanding and recognition with which students receive the language of complexity. Accordingly, I would like to focus on role drama as an entry point into 
complexity theory in education, and in doing so, call our attention to the language of engagement that has emerged in our conversations together. I would like to suggest that role drama is an embodied collective learning system - and that like any "living learning system," small shifts in alliances, perspectives, language, structures, and ways of engagement can create new understandings.

In the following scenario, my students and I engage in a role drama about a miller's daughter who spins straw into gold, designed and led by four pre-service teachers in a drama education course that I teach. ${ }^{1}$ The role drama was designed to explore the benefits and challenges of democracy as compared to rule by monarchy. In our role drama, the student in role as the queen rules her kingdom alongside her two daughters and one son. Other students are in role as merchants, palace servants, guards, the miller and his friends and relations. My role as a tinker is self-selected, informed by a photograph that I had chosen from the many placed inside an envelope. A brilliant blue sky, turquoise ocean, and sandy beach drew me to this photograph. I did not notice, until I held the photograph in my hand, that the ocean vista was fore-fronted by a barbwire fence.

\section{Emergent Interplay}

I am a tinker.

I repair pots and pans, and sell my

wares in the town square. I am unhappy, and consequently, miserable to my customers.

I am trapped in a secret love for the miller's daughter, whose beauty has rendered me silent, too terrified to approach her, to confess my desire.

I pace the cramped quarters of my stall

cursing my ill-fate, grumbling non-stop to my

friend, the baker, who sells his bread and cakes

in the stall next to mine.

He is an optimist, our as-yet unnamed leader of a fledging group

seeking to bring democracy to our kingdom as they plot a peaceful overthrow of the monarchy. Democracy is my friend's entry point into a new way of engaging in the world.

A town crier enters the market and, reading from a scroll, announces the betrothal of the prince to the miller's daughter. The square resounds with a flurry of gossip and concern! Can a prince marry a commoner? What does this mean to the monarchy? A rumour spreads through the crowd-the miller's daughter is imprisoned in the tower, forced to spin straw into gold, powerless to escape. I, the tinker, am devastated by this news-whether imprisoned or married to the prince-she is lost to me.

\footnotetext{
${ }^{1}$ I first wrote about this particular role drama in 2002. In that article, focus is on performative literacy, the embodied understanding that emerges through performative encounters, exploration, and reflection.
} 
The leaders call "Freeze!" and ask each one of us to speak aloud our thoughts at this moment. Thought bubbles, a drama activity often used in role drama, reveal the inner thoughts of those in role, unmasking ambition, motivation, hidden agendas, unspoken emotions. We circle the room, one by one, sharing our thought bubbles.

"Royalty marrying a commoner? Outrageous!"

"This will bring too much power to the commoners in our kingdom."

"A royal wedding! I will make lots of money selling my flowers!"

And then I, the tinker, speak, my words unanticipated.

"I am a caged animal, pacing my cell.

I have no hope, I hate my job, I have nothing."

Why pay attention to role drama, to its engagement between participants, to what unfolds? In my field of drama and theatre education, the relationship between learning and the arts as a pedagogical action-site of learning is recognized as dynamic and generative. Learning through the arts requires from participants a curiosity, critical and creative engagement, and a willingness to inquire in collaboration that which is not-yet known. What interests me in the interplay between complexity in education, performative inquiry, and pedagogy are the performative encounters within role drama that invite new possibilities of understanding. Our engagement and choices of action and interaction within an emergent co-created world offer participants the opportunity to reflect upon what happens, actions taken and why, and the implications of the emergent learning and moments of recognition in connection to our own lived experience, past, present and yet to be realized ${ }^{2}$

I was first introduced to role drama by my thesis advisor, Dr. Patrick Verriour, who worked extensively with teachers and children in role drama throughout British Columbia (See Tarlington and Verriour, 1991). During my doctoral studies, over several summers, I taught an intensive drama education course during which time my students and I would experience three weeks of consecutive role dramas together. Some of these role dramas were developed and facilitated by myself but the majority were created and led by my students. The individual and collective learning I experienced with my students was both breathtaking and humbling, and I have since written a number of articles based on my experiences (See, for example, Fels, 2004, 2002, 1998).

Role drama draws on the work of British drama educator, Dorothy Heathcote, who first introduced the concept of "mantle of the expert" in role play with children. She supported the argument that children learn through doing, and that if given the opportunity to be in the role of "experts," children could explore a wide range of curricular events, both real and imaginary. Role drama is the co-creation of an imaginary world within which one of many possible unscripted narratives unfolds. Students are

\footnotetext{
${ }^{2}$ Moments of recognition are understood as moments of learning that are realized within or upon reflection of a performative encounter. See Fels 1999.
} 
given roles to play within a context and environment that offers them the opportunity to explore creatively and critically the consequences of their decisions and interactions with each other within any given situation. Participants may be in role as town councilors, architects, townspeople, doctors, or police officers (or any other role imagined) and are asked to make decisions and engage in problem solving from the perspective and interests of their roles.

The classroom teacher, who is also in role, facilitates the role drama. A role drama may be one from a given text or designed by the teacher to address particular curricular content or issues. Students in role are encouraged to draw upon relevant information or prior knowledge from previous experience, and engage in problem solving and decision making to address the situation that has been proposed to them, and as it evolves through the role drama. Pedagogically, role drama offers students opportunities for collaborative group work, oral language, critical and creative thinking, writing in role, and improvisation. Role drama provides an action-site for embodied exploration within which interactive experiences, reflection, and collective debriefing surface new learning and understanding across the curriculum (See Fels and Belliveau, 2008).

Engaging collectively in role drama offers us - as educators, teachers, or students - a pedagogical opportunity to take on new roles while continuing to be informed and influenced by our existing roles, responsibilities, values, prior knowledge and experiences. In the process, we co-create an imaginary temporal world that is as-yet unimagined within a framework and logic of a given context and environment. We engage in role drama in order to make a decision, explore a situation, or resolve a problem with the ambition of evoking new insights and understanding of relationships, issues, or concepts. And it is through our actions, and interactions in role, that we may come, collectively and individually, to new learning. Foremost, for those of us in arts education, it is understood that embodied learning opens the possibility for new ways of understanding and engagement. As philosopher David Appelbaum (1995) writes, "Intellect's light sees but is powerless to do. The body's light sees and is able to do" (p. 121).

Complexity theory in education calls the educator to an awareness of teaching and learning that is "more about expanding the space of the possible and creating the conditions for the emergence of the as-yet unimagined, rather than about perpetuating entrenched habits of interpretation" (Davis, Sumara, and Simmt, 2003, p. 228). How we engage, our choices of investigation, and our positioning of relationships and values matter. Davis and his co-authors recognize a classroom or school as "a nested system" and propose that we identify complex systems as they are experienced within education as collective learning systems rather than a collection of learners. They write,

This move toward understanding the collective as a learner or cognizing agent (as opposed to a collection of learners or cognizing agents) presents some important advantages. Most obviously, the teacher or researcher can actually observe the 'thinking' of this agent-that is, the interactions and prompts that trigger new possibilities and insights for the collective. (p. 219) 
They propose that within a collective learning system it is possible to witness how learning emerges through interactive engagement among students within a given environment. They write,

For us, learning is an ongoing, recursively elaborative process through which an agent maintains its coherence with/in its similarly dynamic circumstances. Correspondingly, a learner is an agent, system, or phenomenon that we can identify as having a coherent (but evolving) form. (p. 217)

Enactivist theorists Maturana and Varela (1992), write of cognition as, “... an ongoing bringing forth of a world through the process of living itself" (p. 11, my italics). The concept of cognition as an action bringing forth a new world resonates in my work with drama education, contributing significantly to the conceptualization and articulation of performative inquiry as a research methodology (See Fels, 1996, 1998, 1999). I would like to invite you to think of role drama as an embodied collective learning system - an action-site of curricular exploration in which new possible worlds are called forth or cocreated by those in role within a given context and environment. Within such a dynamic generative system, new learning or understanding emerges.

According to Davis, et al. (2003), for complexity to exist, there are certain conditions that must be present if a collective learning system is to be dynamic and generative (i.e. learning). Of these, I will focus on five: enabling constraints, decentralized control, internal redundancy, internal diversity, and neighbouring interactions. These are not the sole identified characteristics of a complex system, but they are the ones highlighted by the authors and accordingly, I have chosen them to explore in relationship to role drama. ${ }^{3}$ These conditions are present in a role drama as played out and experienced by its participants. The viability and success of an individual role drama, I would suggest, is determined largely by the presence of these five conditions.

I first came across these identified five conditions for a complex system as writing scrawled on the whiteboard located outside a colleague's office next to mine. This professor had recently become curious about complexity theory, learned of these key conditions, and had decided to look into their application in relationship to his work in teacher education. Intrigued, I knocked on his door, and asked him to explain the words he had written on his whiteboard. In turn, he handed me an article, Complexity and Collectivity: On the Emergence of a Few Ideas, written by curriculum theorists, Brent Davis, Dennis Sumara, and Elaine Simmt. We will consider each of these five key conditions or properties as they relate to the role drama in which I was in role as a tinker and see how a group of individuals engaged in role drama may be understood as an embodied collective learning system.

\footnotetext{
${ }^{3}$ Davis et al. (2003) have chosen in their discussion of emergent learning systems, five key conditions, selected and adapted from among lists of conditions described by others (Bloom, 2000; Casti, 1994; Johnson, 2001; Kelly, 1995; Lewin \& Regine, 2000):
} 


\section{Enabling constraints}

Enabling constraints may be understood as a framework and logic of practices: a hierarchy or structure of relationships, rituals, practices, and established forms of engagement which impact significantly on any interactions that occur within a complex system. These constraints set out the parameters of coherency that define and yet enable an agency (i.e. collective learner or complex system) to engage in flexible and responsive movement, interaction, and response. Enabling constraints simultaneously limit and permit dynamic interactions to occur. As Davis et al. (2003) explain, "The rule structures that enable complex systems maintain a delicate balance between sufficient randomness to allow for flexible and varied response and sufficient organization to channel such responses into coherent collective activity" (pp. 224-5). In role drama, participants work within the framework, logic, coherency, and language of a co-created world as defined by context, environment, and roles; within these established yet enabling constraints, choices of action and interaction unfold.

In our role drama on the miller's daughter, the students who designed the role drama incorporated enabling constraints such as the structure and activities of role drama, its context, environment of interaction, issues to be addressed, and roles of participants. One enabling constraint, for example was the pre-established categories from which students could choose their roles: merchants, royal servants, guards, royal family, and the miller's family and friends. As a merchant, I am located within a structure, practice, and language of occupation. My status in the community is already largely determined by what I do for a trade. Living as I do within a monarchy, I am aware of the limitations, the tensions, and restrictions that a monarchy imposes on the community and on my professional and personal life. While working within the constraints established by the role drama and its leaders, I, and my fellow participants, are invited to action, to step forward or not, to resist or accept our situation, and to engage in relationships and interactions within the community in response to unfolding events.

A second enabling constraint were the photographs from which individuals could chose in order to help them establish their roles and personalities, guided by a questionnaire read out by one of the students. Ironically, the photograph I had chosen, had its own enabling constraint, the barbwire fence-this was not the boundless view of possibility I had first responded to on choosing the photograph, but an ocean vista contained and constrained within a given boundary, a constraint that demanded a response. As seen by my thought bubble, "I am a caged animal, pacing my cell," both the metaphor and personality of the tinker (crabby, miserable to my customers) called forth during the role drama emerged through my response to the image of a fenced-in paradise. The feelings and frustrations that surfaced during the role drama, reinforced by the perceived limitations of my life, are illustrated in the photo, a caged beach. That I in role as tinker, and learner, am able to break through this perceived constraint, as seen later in the role drama, opens a valuable opportunity for reflection and learning. The activities that we engaged in during the role drama, such the provision of photographs 
for role development and the series of questions read to us by one of the teachers-in-role that further helped us develop our roles, are examples of enabling constraints.

Constraints imposed within a collective learning system that are too restrictive or too rigidly enacted often result in a system that is eventually unable to creatively sustain or regenerate itself; complex learning systems require flexibility to engage creatively or critically. A role drama requires a fine balance of structured permission and invitation in order to take on a life of its own. It is also readily apparent to participants of a role drama, for example, when someone in role steps outside the constraints given or established by the group: the logic or coherency of the world co-created by the participants within a role drama collapses; inevitably, there is a silence, a groan, laughter (or not); and those engaged through their actions and interactions in role must reestablish the integrity and viability of their shared co-created world together.

\section{Decentralized control}

Decentralized control within a complex system requires that individual components be in a relationship of reciprocity where "control" - the directives of action and interaction-are shared and inter-dependant rather than located in a single entity. Within a collective learning system, no one individual exclusively dictates the actions and interactions that evolve. "The authority in such a setting does not reside in any particular character, argument, or resource. It is genuinely decentralized, and that decentralization is a necessary condition for complex products" (Davis et al., 2003). Responsibility for decisions, choice of action, and collaborating relationships are open to a multiplicity of possible outcomes, as proposed directives for action or decision-making shift from individual to individual, from group to group. Decentralized control is a commitment to an on-going opportunity and invitation for participants to influence or propose action and interaction, not as a one-directional relationship of control in which one single individual or group has sole authority to dictate what happens or how others are to interact.

The responsibility of the teacher within a role drama provides an ideal example of decentralized control in that the teacher takes on a role within the role drama and participates alongside his or her students. Note that the teacher engages in role rather than as an observer or director of events "outside" the role drama. Proponents of role drama emphasize that a teacher in role is most effective when he or she is in role as a guide, questioner, or facilitator, someone who does not know all the facts and so must seek advice, who requests information or solutions rather than gives them. ${ }^{4}$ Whenever a teacher in role predetermines or dominates all actions, preempts or ignores student suggestions, or unduly weights his or her own opinion in collective decision-making, inevitably the role drama in question becomes artificial and imposed. ${ }^{5}$ Decentralized

\footnotetext{
${ }^{4}$ See Tarlington \& Verrier, 1991, Fels and Belliveau, 2008.

${ }^{5}$ See Fels, 2004 for an example of a role drama that collapses because control was too rigidly held by a participant in role as a judge who established criteria of constraints that did not enable students in role as jury members to actively participate in the role drama.
} 
control is a relationship and engagement of reciprocity established between all participants, in which leadership is shared and responsive.

In this role drama, decentralized control is realized immediately by the fact that there are four pre-service students guiding the role drama, each one sharing responsibility and leadership for guiding the visualization, asking questions to help participants determine their roles, and setting up the framework of activities within which the action unfolds. Similarly, individual groups must decide what actions to take, what responses to offer as the narrative unfolds. Control is decentralized as individual groups and individuals respond to any given situation and/or set of actions taken by others. Within the framework of a role drama, participants in role co-create a narrative that may or may not be what those who did the planning previously envisioned. As in any living learning system, surprises are generated, detours are taken, plots unravel, as the narrative world takes on its own momentum.

Decentralized control is an interesting concept within education, as it calls upon teachers to reconsider the perception that they are "in control" of any learning situation. This is particularly evident to any teacher engaged in leading a role drama; the potential success of a role drama depends upon working with students who are willing to collectively and individually engage. As in any learning environment, a sharing of responsibility, sense of agency, and opportunity for choice of action and interaction must be present for learning to emerge. The successful teacher in role becomes a guiding interactive presence able to co-create with his or her students opportunities for occasions $^{6}$ to occur. A dynamic and generative collective learning system is one within which there is ample opportunity and encouragement for unique and individual response and contribution, for emergent leadership, for collective questioning and collaborative engagement.

\section{Internal redundancy and diversity}

A complex system requires both internal stability and creativity or what Davis et al. (2003) refer to as internal redundancy and internal diversity. There must be a degree of similarity of individual components or elements within a complex system in interaction in order for that system to be cohesive and functional. Yet, simultaneously, as indicated by the authors, there must also be a degree of internal diversity among individual students if a collective learning system is to be a generative and dynamic.

Within an educational setting, there is a shared similarity among participants and their relationships with each other. Generally, they are all students-or, as with this role drama, pre-service teachers and teachers-who share a commitment to learning and education, have had common educational experiences, and are engaged in shared activities within a pedagogical environment that allow them to interact together. At the same time, as individuals, they are located in social, cultural, communal, political, and

\footnotetext{
${ }^{6}$ Davis et al. 2003 refers to curricular activities as created by an educator as “occasions” or curricular experiences within which learning may occur.
} 
economic contexts that result in a diversity of individual and communal identities, motivations, perspectives and unique narratives.

Internal redundancy invites a coherency or resonance of engagement; internal diversity within the collective learning system ensures the opportunity for a variety of perspectives and ways of possible engagement that will invite new possibilities to emerge. Individuals who are all similar may work well together but may lack the creative tension that diversity brings to the neighbouring interactions that are critical in an emergent learning system as discussed below. In any classroom or role drama, internal redundancy and diversity amongst participating students is required to allow for generative engagement but the learners do not operate within a vacuum. Their inquiry and context of their learning environment in which they are engaged is critical. As Davis et al. (2003) explain, "The balance of redundancy and diversity among agents-or, in systemic terms, of stability and creativity - is not strictly dictated by the system itself. The context also plays a defining role" (p. 220).

Within the design and population of role dramas, there exist simultaneously internal redundancy and diversity; individuals are assigned roles in groups and each group is assigned a particular problem or task. Sometimes the task is the same as for other groups, other times the tasks are unique to individual groups. In this particular role drama, participants are separated into groups-in-role as merchants, royal family, servants, guards, and the miller and his friends and relatives. Within these categories, individual participants were invited to choose who they wanted to be, or as in the group of royal servants, what kind of service they provided the royal family; the opportunity for participants to specialize resulted in a variety of occupations and responsibilities within individual groups. Among the group of merchants, for example, one participant in role chose to be a baker, while I chose to be a tinker. Amongst the royal servants, one participant was a cook, another a gardener, while a third washed the royal laundry.

Groups in a role drama may be given a similar task and yet each group will tackle the same task or respond to an event depending on their agenda, perspective, or motivation. For example, when asked to establish the town square, the merchants set up their stalls, the guards positioned themselves at the town gates or accompanied the royal family who strolled around the market as the royal servants attended their needs in the castle, which was located by the servants in the right side of the room. The participants' roles and their reading of those roles determine how and with whom they will interact as the role drama unfolds. ${ }^{7}$ On news of the royal engagement, for example, the thought bubbles evoked reflected the positions and concerns of the individual groups; one merchant celebrated the potential for increased flower sales, while a member of the royal family worried about the danger of giving the commoners "too much power." I, the tinker, on the other hand, lamented my impotency and imprisonment within a system I could not change.

Each group, whether in role as royal family members, merchants, or palace guards, may be involved in the same problem-solving activity, however they will approach it

\footnotetext{
${ }^{7}$ See Fels (2002) for a discussion on performative literacy as enacted within performative encounters.
} 
from a particular perspective or objective, both as a group and from individual participation. The diversity of response to a similar task assigned to all the groups is illustrated in the second part of the role drama when the individual groups are asked to make placards in anticipation of a rally to be held in support of (or against) the monarchy. The diversity and redundancy of roles assigned to individual groups and the unique and shared characteristics of and possibilities of response by participants within each shared group ensure the degree of complexity required for a collective learning system to operate.

\section{Neighbouring Interactions}

A critical and essential condition for a complex learning system is inherent opportunity for neighbouring interactions - the emergent possibilities of learning as individuals interact with and respond to each other. Within these interactions and interrelationships, shifts of movement, response or composition generate possibilities of new relationships, new interactions, new engagements, new recognitions. It is not the interactions between participants per se that matter so much as what is generated by those interactions, how the sharing of ideas, questions, interpretations, and emotional, physical, or intellectual actions and responses "bump against" each other. As Davis et al. (2003) explain,

The neighbors in a knowledge-generating collective are not physical bodies or social groupings. In fact, direct personal interactions may not be as vital as is commonly assumed. Rather, the neighbors that must interact in a knowledge-generating collective are ideas, hunches, queries, construals, and other manners of representation. Knowledge emerges not simply amid the juxta-position of bodies, but amid the juxtaposition of interpretive possibilities. (p. 220)

A generative and dynamic collective learning system is one embodied within an actionsite of inquiry within which a curricular activity of exploration is shaped by the questions, interests, contributions, responses, and ideas of all participants in interaction with each other, in and out of role. Through these shared experiences and conversations, new ideas, possibilities, choices of actions may be recognized and initiated.

Such sharing of ideas and questions and responses in action and interaction are the neighboring interactions required for learning to emerge. In any role drama, as groups and individuals interact in role, possibilities for new ideas, new ways of engagement with others emerge. The unfolding of our second half of our role drama illustrates the learning that may emerge within a living learning system that is open to a wealth of emergent neighboring interactions.

\section{Stepping forth}

After our break, we are led into a room where supplies for making placards are laid out on tables. We are told to prepare a placard in our assigned groups. The baker and I choose a white piece of poster paper, and take up a black marker. What should our slogan say? I don't know. Any thoughts? None. We watch as others design their placards, bending to their task, vibrant colours and slogans spilling onto the white sheets of paper. We are 
hesitant to mark our paper. Thought of anything yet? No, but it matters what we write. One of the role drama leaders, noting our failure to take action, tries to hurry us along but still we resist, seeking words that remain just beyond our reach, then, finally, they come, and we write them down, nothing else, just these words-

Walls do not a prison make.

Joining the others, we march around the outside of the building, startling passing students as we wave our placards, and vigorously shout our slogans.

"Down with the Monarchy!"

"Three cheers for Democracy!"

"Freedom is one vote per person!"

"Hurray for the Queen!"

"Democracy lovers go home!"

We enter the grand room, two opposing sides facing each other, shouting loudly, our placards held high in protest. And then, time stops. A man steps forth from amongst the crowd, and says,

"I am your king. For three months I have lived among you, in disguise. I have listened to what you have said, watched you in action with each other. And now I will take my rightful place upon the throne."

And with a single breath, the crowd kneels in the presence of their king-a collective response, a public declaration of alliance, a motion of complicity, of compliance, of acknowledgement of authority. Nearby, now disturbingly visible, a noosed rope had been placed on a podium between the two opposing sides of protesters, as if in anticipation of this moment. The appearance of the king, however, was unplanned by the role drama leaders, he simply emerges amongst us, as if called upon to take action. As the king sits upon his throne, we frantically try to recall our interactions with him in the past hours.

What did I say when I thought he was just a commoner? Does he know I plotted against the monarchy? Will he remember the kind words I said about the royal family?

He glares out over the crowd. He admonishes those of us for protesting against the monarchy; he praises those who stood fast in the name of the monarchy. He points to my friend, the baker, and says, "You, approach the throne." We wait with bated breath - a fledging democracy to be terminated, the baker to hang from a noose, a new possible world silenced....

And then I, the tinker, step forward, 
"My liege, it is I who is the leader calling for democracy, it is I who is responsible. It is I, not the baker that you want."

I had everything and nothing to lose.

And in that moment, poised within what Appelbaum (1995) calls the stop, a momentary glimpse of the possible, I suddenly understood how Nelson Mandela could survive twenty-seven years in a prison cell. I understood how a young man could choose to step in front of the tanks as they rolled towards Tiananmen Square. And I came to understand how a life might be lived within the walls of one's own limited construction.

\section{Walls do not a prison make}

How curious that my tinker's stall, indeed my life as I perceived it in role as a tinker, had been a constraint within which I initially felt unable to act, yet when my relationship with the baker was threatened, when I perceived that his dream for democracy was at risk, I enacted to call forth a new response, one not expected of a cantankerous tinker who thought only of his own misery. The impulse to stand forth to protect my friend brought into play a clarity of individual agency and responsibility of engagement that I had not initially imagined in my position in role as the tinker.

New understandings and questions may emerge through our interactions together in role, informed by our imagination, lived experience, personal and collective narratives, points of view and perspectives that we embody individually and communally. The choices of action and interaction taken become locations for reflection both during and following the completion of the role drama.

Why did everyone kneel simultaneously in the king's presence? What happens within a monarchy when divine right is questioned? What motivation calls us to step forward to protect another? How might we understand what happened during our role drama in terms of our lived experience, how we might choose to engage with others in the future? What did I learn in role as tinker, that embodies who I am, and who I might yet become?

A shifting of positioning or perspective opens up new possible ways of engagement. The participant who steps out of role as the miller and into a new role as king required those of us in role to engage anew in response to his presence, our actions becoming appropriate to those in the presence of a king. Upon his pronouncement, "I am your king," as if in a single breath, we kneel in his presence. And yet, in doing so, this collective kneeling in the moment and upon reflection generate new questions that challenge our ethical choices of action in role, as individuals and educators.

In role drama, something happens that calls our attention to the moment. In my work in performative inquiry, I refer to this moment as a "stop," calling upon the writing of philosopher, David Appelbaum. In his book, The Stop, Appelbaum (1995) calls forth the presence of a blind man, a minor character in Descartes' writing, who looms large in Appelbaum's philosophical stance as a reminder that as individuals, we must 
re-embrace embodied presence and enactment. In his retelling, Appelbaum's blind man journeys along unfamiliar terrain, guided through the aid of his cane. Arriving at a literal and figurative crossroads, he encounters what may be perceived as a possible obstacle or opportunity. It is a stop. A stop is a moment of awareness when the blind man realizes that he must actively decide on a choice of action, not knowing what will unfold, what will become of him, nor the consequences of the action he will take.

A stop is a moment before the moment of decision, but in that moment, an individual realizes that which he or she has not yet known before: that he or she must choose, not blindly, or in response to habits of engagement, but with full awareness that there are choices of action available. Appelbaum explores the stop as a moment of risk, a moment of opportunity, in which action is momentarily suspended, yet anticipated as we are called to awareness of renewed engagement and possibility. Appelbaum calls a stop "the advent of an intelligence of choice" (xi).

A stop is a moment that calls us to attention, in which we become aware that what we have known is but "one possible world."

\section{Between closing and beginning lives a gap, (a caesura, ) a discontinuity. \\ The betweenness is a hinge that belongs to neither one nor the other. \\ It is neither poised nor unpoised, yet moves both ways...}

It is the stop.

(Appelbaum 1995, p. 15, 16)

Awareness and recognition of individual and collective stops as they unfold through role drama and other performative encounters are what we seek as educators-an awakening to what may be possible and what we have failed to notice that comes to us in a moment of recognition, realized through interplay within embodied performance. Role drama is an action-site of learning that offers participants the opportunity to bring forth one of many possible worlds, and in doing so, consider their choices of action as they identify the stops that called them to attention. The stop and the learning that emerges within the moment of the stop and upon reflection is what comes into being through neighbouring interactions within a dynamic and generative embodied collective learning system when all the conditions are in presence and participants are actively and meaningfully engaged.

Resonance between complexity theory and performative inquiry calls me to respond to the whiteboard with its curious writing. I first stumbled upon the connection between complexity and role drama years earlier when I turned to the etymological dictionary in our university library and looked up the word performance. The etymological connection between performance and complexity theory was one of my first steps in coming to conceptualize and articulate performative inquiry as a research methodology and pedagogical action-site of learning. ${ }^{8}$

\footnotetext{
${ }^{8}$ This section briefly reintroduces my discussion of performative inquiry in an earlier article published in Complicity. See Fels, L., 2004. Complexity, Teacher Education and the Restless Jury: Pedagogical
} 


\section{per/form/ance}

The meaning of form is evident (i.e., structure) and ance is easily understood as "action" (e.g. dance). However, it is the prefix per that calls us to attention. Per-meaning "through"-defines the word adjacent to it, so that speaking etymologically, we may translate the word performance as, "through form we come to action." However, per is delightfully complicit as it may also mean "through the destruction of." 9 Thus, in a moment of sleuthing, I discover that per/form/ance may be read as "simultaneously through form and through the destruction of form we come to action."

Etymological play with our word per/form/ance brings us unexpectedly into the playground of complexity, a generative dynamic space of learning where, as Mitchell Waldrop writes in his book Complexity: "components of a system never quite lock into place, and yet never quite dissolve into turbulence, either...the one place where a complex system can be spontaneous, adaptive, and alive" in "an endless dance of coemergence" (1992, 12). Cognition is ever evolving, an embodied engagement of "knowing, doing, being, creating" (Fels, 1995). Performance then, may be understood as an action-site of learning and inquiry. In my experience, role drama offers participants the opportunity for dynamic, generative spaces of learning-each stop an awakening that calls us to ourselves and to each other. And so it is, that an arts educator finds welcome within complexity theory as it relates to performance and the living learning system that role drama within education enacts. Complexity theory, in part, is an acknowledged underpinning of the theoretical framework of performative inquiry.

Performative inquiry through role drama offers educators and students an opportunity to bring into being new possible worlds through performative encounters. Performative inquiry calls us to awakeness, as we encounter each other within and out of roles, individually and collectively seduced, driven, interrupted, guided, corrupted by our desires, our fears, our hopes, our ambitions, our frailties. What matters is the emergent learning that comes through our engagement with each other, within a context and environment, through inquiry and reflection, in response to our curiosity that invites us to ask what happens if?

\section{Releasing expectations}

There is a sixth term written on the whiteboard when I first come across it, and the following day, after returning the article he had lent me, I point to the line of writing, and ask the professor,

"What about this one? It wasn't in the article."

Moments of Performance, Complicity: An International Journal of Complexity and Education, 1 (1). www.complexityandeducation.ualberta.ca/publications.htm

${ }^{9}$ This etymological reading of the word per/form/ance has been explored in my doctoral thesis in the wind, clothes dance on a line, and in earlier work regarding the conceptualization and articulation of performance as an action-site of learning. See Fels 1999, 1998, Fels \& Stothers 1996. 
"Ah!" He pauses, and then reads it aloud, "Releasing expectations. Yes. This too matters."

"How so? What expectations? And whose?"

"Well, that's it exactly." And he proceeds to remind me that the learning that happens in our presence is often not what we as educators anticipate nor studiously designed our lesson plans to accomplish. This is the learning that happens when we least expect it, when we are, as educator Maxine Greene (1978) advises, "wide-awake" to new possibilities, to the moral implications of our choices of action, to those shared moments of recognition that are the gift of dynamic learning systems. Most importantly, we must continually be aware that how we come to engage in that desire or quest is shaped by the context, environment, language and action of our endeavors. Our presence, our absence, our language and practices of engagement within the context and location of our interactions, and relationships, matter. As Davis, Kieran, and Sumara remind us, "just as I am shaped by my location, my location is shaped by my presence" (1996, p. 157).

When I first engaged in role drama and had classes back to back, I discovered that the same lesson plan, same role drama, would yield different experiences. Not a surprise of course, as one would expect given the time of day, the different students involved, the diversity of interests, perspectives, and knowledge they brought to the role drama. But there seemed to be something forced in the afternoons; the spontaneity, the curiosity, the excitement I experienced in the morning class was oddly lacking in the afternoon. The mornings' role drama would unfold with its surprises, moments of recognitions, stops, unexpected turning points, and I would approach the afternoon class, with eagerness, already anticipating what would happen, how the role drama would play out, what we would learn together. Yet, inevitably, when I tried to direct the action or introduce situations that had proven pivotal in the morning, the role drama would become didactic, without energy.

"What is wrong with you guys?" I asked one afternoon, "This morning we did this amazing-"

And suddenly I saw with clarity that MY expectations were the limitations of our engagements together. To release expectations is to give permission and invitation to those participating in a learning experience to be actively engaged; whether it is engaging in a role drama or figuring out a math solution, participants need to feel that their presence matters. To release expectations as an educator and student is to be open to alternative solutions, to be eager for detours, to be able to embrace the unexpected, to embody a sense of agency and relevancy.

A learning system that has the end view in sight already limits the possibilities of its horizons and those participating. I am reminded of the student who once replied to a professor in response to her question, "Why don't you tell us? You already know the answer." Our challenge as educators is to be alert to the habits of engagement that Greene (1978) warns us about, recognizing that our limitations are often those that we individually, and communally, co-create in our encounters together. "What we do," Varela (1987) says, "is what we know, and ours is but one of many possible worlds. It is 
not a mirroring of the world, but the laying down of a world..." (p. 62). The world we choose to enact reveals to us who we are, and the absence of who we might yet become.

The next day two of the pre-service students who had led the role drama came to me, wanting to share their experience. They tell me that their group had designed the role drama to explore issues of citizenship within political structures of government. They tell me how the role drama as it was realized by the group radically diverted from their original plan-I vividly remember seeing these two students consulting with their co-planners during their role drama, pointing at their role drama outlines, gesturing in dismay. As the role drama unfolded, it became apparent that our performance encounter had taken on a life of its own-prisoners escaping from prison, plots hatched against the monarchy, secret meetings organized to rescue the miller's daughter, individuals in new roles coming into play. The role drama became an organic collective entity that shifted and flowed in response to the evolving relationships, actions, and interactions between participants. Finally, we realized that it was out of our control, they told me, we had to let go of our script, to see what would happen.

And in this letting go, releasing their expectations, in decentralizing control, their role drama became their "stop" as emergent teachers. Through their experience, and upon reflection, they came to understand that to guide and engage students through a curricular enterprise requires a releasing of expectations, a decentralizing of control, and a willingness to be responsive and attentive to the dynamic landscape unfolding before them. Doing so, they learned, opens up new possibilities, calls forth student voice and responsibility, and facilitates new directions for curricular explorations in ways of engagement that we might call a democratic process of learning. The learning was theirs as new teachers in how to be in relationship with their students: to allow events to emerge, to listen in response to the curriculum as it emerges, to invite agency in their students, to recognize the integrity of a curricular experience, in this case, the role drama, to bring forth new possible engagements of learning.

And as participants-in-role in the role drama, they questioned their own choices of actions.

Why did we kneel when the king stepped forward? Why did we not interrogate this newcomer? Or question his right to sit on the throne? And when you stepped forward to protect the baker, why did we too not step forward to support you? If we cannot speak out in a role drama, does this mean we will choose to be silent in the face of authority? What does our experience mean in terms of how we will choose to act in our own lives beyond the role drama?

This too is a stop.

A stop calls us to reflect upon how we are shaped by actions and language of habit, authority, location and context. The critical question becomes: How do we interrupt our habits of engagement? How do we now engage? What is it that I might learn in this moment of recognition? 
When we speak of neighboring interactions, enabling constraints, and decentralized control, of internal redundancy or diversity, and releasing expectations, we are speaking to a living entanglement of emergent relationships that is learning through the intimacy of human engagement. These engagements occur within a context and environment that is rife with hidden agendas, motivations, conflicting perspectives, desires, fears, and ambitions. What matters to those of us interested in pedagogy, is the learning that becomes possible when we pay attention to how we engage our students within curricular explorations that matter and are of relevance.

Complexity theory with its dynamic generative systems, and its language of enabling constraints, and decentralized control, invites educators to consider pedagogy through a new lens, to move beyond the scripts and lesson plans to understanding how cognition is embodied and performed within a collective learning system, and that, as educators, we need to pay attention to the components and conditions of a vibrant collective learning system. Complexity in education introduces new language, and with new language, new metaphors with which to understand our practice. The invitation to visual and performing arts educators to participate in the unraveling of what matters in complexity in education invites a neighboring interaction that brings its own surprises.

Embodied within my own understanding of complexity in education and performative inquiry is the interplay of breath, presence, and absence within the intimacy of relationship, time, engagement, inquiry, language, and location. ${ }^{10}$ The emergent learning that comes through our engagement together occurs within multiple frameworks of relationships and interactions that seek to define who we are, the narratives we create within which we journey, the unknown yet to be realized through our creative actions and interactions. Theatre director, Eugenio Barba, speaks equally to complexity theorists as he does to educators and theatre activists, as he calls us to attention to what matters within creative encounters if we are to generate new meaning, new life, new learning together,

"not walls of cements, but...

the melodies of your temperature" $(1995,162)$.

When royalty steps forth, how do we respond? And in doing so, what is the desire, fear, yearning, the as yet unknown possibilities embodied within our response? What impulse, what awakening, comes to us in a moment of recognition that is our educational quest of communal envisioning through performative play? As Davis et al. (2003) remind us,

The emphasis is not on what is, but on what might be brought forth. Thus learning comes to be understood as a recursively elaborative process of opening up new spaces of possibility by exploring current spaces. (p. 228)

\footnotetext{
${ }^{10}$ See Karen Meyer's writing on living inquiry in which she identifies place, language, self and other, and time as critical to understanding how we live and engage in everyday life. See Meyer, 2006.
} 
The gift of complexity theory in education is that it has given those of us in arts education yet another way to articulate the practices embodied within the learning that arises through and within the arts. In return, we offer a lively pedagogy of engagement that resonates with the ambitions of complexity in education theorists: the conceptualization and articulation of an embodied collective learning system at play.

"Releasing expectations. I like it," I say, scribbling the term down on my notebook. "I'll expect you to cite me," says the professor.

And so, quite unexpectedly, I will. ${ }^{11}$

\section{References}

Appelbaum, D. 1995. The stop. Albany: State University of New York Press.

Barba, E. 1995. The paper canoe: a guide to theatre anthropology. (trans. by Richard Fowler). London: Routledge.

Barnart, R. K. (Ed.). The Barnart dictionary of etymology. 1988. U.S.A.: The H.W. Wilson Company.

Davis, B., Kieren, T., and Sumara, D. 1996. Cognition, Co-emergence, Curriculum. Journal of Curriculum Studies, 28 (2): 151-169.

Davis, B., Sumara, D., and Simmt, E. 2003. Complexity and Collectivity: On the Emergence of a Few Ideas. Proceedings of the 2003 Complexity Science and Educational Research Conference October 16-18, Edmonton, Alberta. www.complexityandeducation.ca

Fels, L. \& Belliveau, G. 2008. Exploring curriculum: Performative inquiry, role drama and learning. Vancouver, BC: Pacific Educational Press.

Fels, L. 2004. Complexity, Teacher Education and the Restless Jury: Pedagogical Moments of Performance, Complicity: An International Journal of Complexity and Education, 1(1): 73-98. 2002. Spinning Straw into Gold: Curriculum, Performative Literacy and Student Empowerment. English Quarterly 34 (1 \& 2): 3-9. 1999. in the wind clothes dance on a line-performative inquiry as a research methodology. Unpublished doctoral dissertation. University of British Columbia, Vancouver, B.C. 1998. In The Wind Clothes Dance On A Line. Journal of Curriculum Theorizing. 14 (1): 27-36. \& Stothers, L. 1996. Academic Performance: Between Theory and Praxis. Drama, culture and education.

(O'Toole, J. ed.). Australia: IDEAS. 255-261.

1995. Cross-country with Grumet: erasing the line. Educational Insights, 3(1), October 1995. See Archives. www.educationalinsights.ca

Greene, M. (1978). Landscapes of Learning. New York, N.Y.: Teachers College Press.

Maturana, H. \& Varela, F. 1992. Tree of knowledge: the biological roots of human understanding. (Revised Edition). Boston, USA: Shambhala.

Meyer, K. 2006. Living inquiry: A gateless gate and a beach. In W. Ashton and D. Denton (Eds). Spirituality, ethnography, and teaching: Stories from within. NY: Peter Lang.

Tarlington, C. \& Verriour, P. 1991. Role Drama. Portsmouth, NH: Heinemann.

Varela, F. 1987. Laying Down a Path in Walking. In W. I. Thompson (ed.), GAIA: A way of knowingpolitical implications of the new biology. Hudson, NY: Lindistarne.

Waldrop, M. Mitchell. 1992. Complexity: The emerging science at the edge of order and chaos. New York: Simon \& Schuster.

${ }^{11}$ Dr. Tony Clarke, in conversation by the white board outside our offices, University of British Columbia, 2006. 
Vignette: When Royalty Steps Forth

\section{Acknowledgements}

A version of this article was presented at the Fourth Conference on Complexity Science and Educational Research, at the University of British Columbia, Vancouver, British Columbia, 2007 February 18-20. I would like to offer my sincere appreciation to the conference organizers and editors of the journal, Complicity. My thanks, also, to Dr. Anthony Clarke, Faculty of Education, University of British Columbia, to whose whiteboard, humour, and sustaining conversations, I am truly indebted. Also to Drs. Karen Meyer, Brent Davis, Carl Leggo, and Patrick Verriour, whose work and writings have brought a richness of complexity and insight to my own understanding and practice of my work.

\section{About the author}

Lynn Fels joined the Faculty of Education at Simon Fraser University, as Assistant Professor in September 2007. She is currently the Academic Editor of Educational Insights, www.educationalinsights.ca. Her research interests are arts education, curriculum, teacher education, writing, and arts for social change. Exploring Curriculum: Performative Inquiry, Role Drama and Learning, co-authored with George Belliveau, was published by Pacific Education Press in January 2008.

(c) Copyright 2009. The author, LYNN FELS, assigns to the University of Alberta and other educational and non-profit institutions a non-exclusive license to use this document for personal use and in courses of instruction provided that the article is used in full and this copyright statement is reproduced. The author also grants a non-exclusive license to the University of Alberta to publish this document in full on the World Wide Web, and for the document to be published on mirrors on the World Wide Web. Any other usage is prohibited without the express permission of the author. 